\title{
A Short History of Conscience, Authorty and Obedience
}

\section{Vicdan, İtaat ve Otoritenin Kısa Bir Tarihi}

\author{
Nedim Yıldız
}

${ }^{1}$ Assoc. Prof. Department of Philosophy, Faculty of Letters, Istanbul University, Istanbul, Turkey

\section{ORCID: N.Y. 0000-0002-0113-7127}

\section{Corresponding author/Sorumlu yazar:} Nedim Yıldız,

Department of Philosophy, Faculty of Letters, Istanbul University, Istanbul, Turkey

E-mail/E-posta: nedimyildiz@istanbul.edu.tr

Submitted/Başvuru: 02.10.2018 Revision Requested/Revizyon Talebi: 11.10.2018

Last Revision Received/Son Revizyon: 16.10.2018

Accepted/Kabul: 22.10 .2018

\section{Citation/Atıf:}

Yildiz, Nedim. "A Short History of Conscience, Authorty and Obedience." Felsefe Arkivi 49 (2018): 1-12

https://doi.org/10.26650/arcp2018-589758

\begin{abstract}
The issue of conscience and authority has long been on the agenda of moral philosophy. In particular, the views of John Locke and Thomas Hobbes came to the fore when there was freedom of religion and conscience. Their views continue to influence the moral philosophers of today's world. In terms of organizing and maintaining individual and social relationships, different perspectives from past to present have been made possible by taking into account the common life practices. In today's world, the social configurations that have changed compared to the past and the problems arising from the encounter of different ethnic and social groups have caused re-emergence of solidarity in a common theme. The concept of cultural relativism, which is one of these common themes, refers to the evaluation of exposed judgments within the internal dynamics of culture. On the other hand, shaping of universal human rights and social solidarity on an intercultural ground makes the existence of an additional theme inevitable in terms of harmony and sustainability: conscience.

Conscience is related to the commonization of the common living commitments and being in solidarity in sustaining social relations. Predicating the relations to be formed on the basis of conscience upon an essentialist foundation does not run parallel to the continuous reshaping of solidarity in practical life. In the absence of essentialist truths, and outside the original ethnic relativity, a new and sustainable togetherness starts to be shaped within these practices. Therefore, one of the themes that will spring to mind will be the values education. There are studies that include the answers given to the questions that come to mind about the theoretical possibilities of this and the determination and interpretation of the values already positioned in the practical structures.
\end{abstract}

Keywords: Conscience, obedience, authority, Synderesis, John Locke, Thomas Hobbes, Stanley Milgram, Erich Fromm, Agnes Heller

\section{ÖZET}

Vicdan ve otorite konusu uzun zamandır ahlak felsefesinin gündemindedir. Özellikle, John Locke ve Thomas Hobbes'in görüşleri, din ve vicdan özgürlüğü söz konusu olduğunda ön plana çıkmıştır. Onların görüşleri, bugünün dünyasının ahlak felsefecilerini etkilemeye devam etmektedir. Bireysel ve toplumsal ilişkilerin düzenlenmesi ve sürdürülmesi açısından geçmişten günümüze değin benimsenen faklı bakış açıları gelmiştir. Bu farklı bakış açılarının imkanı, ortak yaşam pratiklerinin 
göz önüne alınmasıdır. Günümüz dünyasında, değişen sosyal yapılanmalar ve bir araya gelen farklı etnik ve toplumsal grupların birbirleriyle karşılaşmasından dolayı pek çok problem açığa çıkmaktadır. Bu problemlerin çözüm denemeleri, ortak temaların bulunmasına bağlıdır. Bu ortak temalardan birisi olan kültürel görelilik anlayışı, farklı kültürlerden gelmiş olmaktan kaynaklanan ahlaki yargıların, kültürlerin kendi iç dinamikleri içinde değerlendirilmesi gerektiğine göndermede bulunur. Diğer yandan, evrensel insan hakları ve sosyal dayanışmanın kültürler arası zeminde şekillendirilebilmesi ve sürdürülebilmesi, ek bir başka temanın varlığını kaçınılmaz kılar: Vicdan.

Vicdan, sosyal ilişkilerin sürdürülmesinde ortak yaşam bağılıklarının kişiler arasında müşterek kılınmasıyla ve dayanışma içinde olunmasıyla ilişkilidir. Vicdan zemininde şekillenecek ilişkilerin özcü bir temele dayandırılması anlayışı, dayanışma aracılığıyla pratik yaşamdaki ilişkilerin ve değerlerin sürekli yeniden şekillendirilmesi anlayışıyla paralellik göstermez. Dayanışma, özcü hakikatlerin bulunmadığı zeminde ve etnik göreliliğinin ve sürdürülebilir birlikteliğin pratikleri içinde değerlerin şekillenmesiyle açığa çıkar. Bu çalışmanın amacı, Aydınlanma döneminde vicdan, iktidar ve otorite arasındaki ilişkiyi, özellikle de İkinci Dünya Savaşı́nda yaşanan trajediler üzerinden tartışmak ve bu konudaki bazı filozofların çözüm önerilerini betimleyerek değerlendirmektir.

Anahtar Kelimeler: Vicdan, itaat, otorite, Synderesis, John Locke, Thomas Hobbes, Stanley Milgram, Erich Fromm, Agnes Heller

One of the reasons for the discussion of the conscience by different schools and thinkers in different periods is that there is no satisfactory answer to the developments in the practical world that could be given by the intellectual hegemony of the period. One of the last examples comes from Western European moral philosophers who raised the issue of conscience and values in order to analyze the tragedies of the Second World War and to prevent re-occurrence thereof. It is also important that the subject was addressed not only in the recent past but also in the Western Middle Ages, which would also influence classical thinkers. This importance stems from the criticism of the dominant thought of the period in which truth and conscience are thought to be directly related. With the emergence of the fallible conscience, a new era begins that would affect the shaping of the ground that is conducive to striking and different interpretations.

Philip the Chancellor and Bonaventura, both Western Medieval thinkers, are the philosophers at the threshold of this change. Philip the Chancellor states that conscience is composed of two elements and that the synderesis is directly related to the divine and the conscientia to the world. According to Philip, the synderesis and the sum of the free choice made with it makes conscientia true or inaccurate. Conscientia is closer to reason. ${ }^{1}$ Although the two bonds are not completely cut off, conscientia is fallible and relative because it is more intertwined with the reasoning and man's cultural backgrounds. Philip states that such erroneous situations are due to a lack of faith. At such times, the effect of synderesis can be very weak, while the effect of constientia can grow very large and dominate all actions. But the spark of the conscientia, the synderesis alone, as its actuator, is free of all effects and error-free. ${ }^{2}$ Nevertheless, the effect of conscientia can lead a person to believe in everything he believes in already and to believing in death for this purpose. ${ }^{3}$ In this respect, the error arises from the judgment of the free will that is influenced by the synderesis. ${ }^{4}$

1 Timothy C. Potts, Conscientia in Medival Philosophy, Cambridge University Press, 1980, p. 12.

2 Ibid., p. 12.

3 Ibid., p. 13.

4 Ibid., p. 14. 
Bonaventura, on the other hand, accepted the same distinction, but instead focused on conscientia. ${ }^{5}$ The first aspect of conscience is related to the discovery of the realities of practical reason by representing the illusory and divine. For Bonaventura, this part of conscience is as infallible as it is from birth. ${ }^{6}$ The second part of conscience performs the proceedings on the relative situation. The first side is the synderesis, which the human sees as a spark that does not occur and does not differ depending on the experiences of the inner life of the human being. The second side is located as conscientia, which is acquired by a certain life experience and differentiated over time for application and reasoning. "The second part of conscience concerns the application of the very general principles to situations which may be either general or particular." Here conscience is seen as a duality. While the synderesis, which is the first part of this duality, has an intrinsic quality, conscientia externally represents the general belief and shared values. This sharing means sharing with someone else. ${ }^{8}$ There is natural law at the center of Bonaventura's addressing synderesis and conscientia. He confirms that synderesis and conscientia are different from each other. But thought that they were related to the understanding and realization of the natural law. For him, the natural law is something known through conscientia.? In the absence of the synderesis, which he associates with natural law and moral motivation, conscientia will remain aimless and lose its path in the realization of morality. ${ }^{10}$ According to Bonaventura, conscientia, which determines the judgements for behavior, is partly inherited and partly acquired. ${ }^{11}$ What is important about the latter is the lack of innate light without education and good manners in comprehending reasoning? "Moreover, apprehension of the particular conclusions of [the various branches of] knowledge is acquired in that the light which is innate to us is not enough to apprehend them, but demands some persuasion and a new aptitude. This is also to be understood as applying to deeds, which are things to be done and to which we are bound, which we only appre-hend by additional education (Translations, pp. 113-114)"12 In addition to the fallibility of conscience, this idea is also present in the works of philosophers such as Hobbes, Locke, Smith and Kant. The fundamental motto being: "Conscience is fallible and man should be trained to find the moral good".

The reason why Thomas Hobbes (who represents the first example of this understanding), emphasizes the fallibility of conscience is because he wants to debilitate the efforts of the clergy, the dominant force of the period, to use the theme of conscience to overcome the laws of the state. ${ }^{13}$ Thus, Hobbes wanted to place conscience in a new position that would contribute to

5 Ibid., p. 32.

6 Douglas Langston, The Spark of Conscience: Bonaventure's View of Conscience and Synderesis, Franciscan Studies, Volume 53, 1993, pp. 79-95, p. 80.

7 Ibid., p. 81.

8 Paul Strohm, Conscience, A Very Short Introduction, Oxford University Press, New York, 2011, p. 8-11.

9 Timothy C. Potts, p. 32.

10 Ibid., p. 32.

11 Douglas Langston, p. 81.

12 Timothy C. Potts, p. 36.

13 Mark Hanin, Thomas Hobbes's Theory Of Conscience History Of Political Thought. Vol. Xxxiii. No. 1. Spring 2012, p. 59. 
the state's continuity and not to be a source of inspiration for opposing the state in which he lived. ${ }^{14}$ For Hobbes, conscience is related to the continuity of the inner peace of the state and the adaptation of the citizens to this peace. Moreover, for Hobbes there is hope of a good devotee's salvation. Hobbes emphasizes two different aspects of conscience, one being the personal side and the other being related to values, by indicating that the personal side is free, on the condition that none of the supplies and desires of any kind are put into action. ${ }^{15}$ The other side of conscience is public conscience ${ }^{16}$ which represents earthly authority; every human being must act according to this understanding in the public sphere. So Hobbes's aims to offer a new approach to the notion of conscience by considering the law of nature: he wants to ensure the continuation of the obedience to protect the environment of peace. ${ }^{17}$

The tension between the religious and state structures of the period also spread to the issue of conscience. Hobbes treats the notion of conscience from a state-centric perspective. According to him, all ideas that could be harmful to the state are caused by 'erroneous' conscience. This is related to sin. According to this understanding, it is a sin to act against people's own conscience. ${ }^{18}$ In the paradigm established in the form of state laws $v$ s. laws of nature, the synderesis, which is stated to act from the laws of nature to overcome the laws of the state by not obeying the laws of the state, in Hobbes' view is "false conscience". This error arises from the fact that the synderesis itself, according to Hobbes is not faulty, but the ground of justification that the person tries to find for himself due to either his false reasoning or his bad intentions is what is at fault. ${ }^{19}$ The concept proposed by Hobbes to avoid possible mistakes is "public conscience"; a synonym for social law. The main problem for Hobbes is to prevent the risk of reduction in the level of obedience to the state due to the understanding of multiple consciences arising out of different understandings of conscience. If peace, the greatest responsibility of the individual, cannot be maintained, everyone will act according to their own conscience and it will be impossible to live together in peace. ${ }^{20}$ Any condition of conscience that contradicts these laws is wrong. ${ }^{21}$ Whereas the synderesis maintains its infallible connection with the natural law, it is (in)fallible? due to the reasoning required to make decisions on earthly matters. ${ }^{22}$ The dilemma here can only be

14 Ibid., p. 76.

15 Hobbes's Leviathan, Reprinted From The Edition Of 1651 With An Essay By The Late W. G. Pogson Smith, Oxford At The Clerandon Press, London, 1965, p. 223.

16 According to Hobbes, conscience should not only be an inner side, but also a publicity that all the public should share. Bkz.: Paul Strohm, p. 90.

17 Hobbes's Leviathan, p. 249.

18 Ibid., p. 249. And, De Cive, p. 147. Thomas Hobbes, De Cive, Edited by Howard Warrender, Oxford At The Clerendon Press, 1987. The common theme of Hobbes's account of conscience in The Elements, De Cive, and Leviathan is: It is against the law of nature to do what is forbidden by conscience. See: Mark Hanin, p. 59.

19 Mark Hanin, p. 62.

20 Thomas Hobbes, The Elements of Law Natural and Politic. Edited With A Preface And Critical Notes By Ferdinand Tönnies, Simpkin, Marhall, and Co., London, 1889, p. 146.

21 Bu bakımdan Kral Oidipus'un kızları olan İsmene ve Elektra’nın durumu, Heller göz önünde bulundurularak değerlendirilecektir.

22 From Hobbes's point of view, one might ask: how can the connection be established with the law of nature, which is always referred to in conscience? Some scholastic and 17th century philosophers suggest the synderesis to solve the problem. "Synderesis — a possible corruption of 'suneidesis', the Greek word for 'conscience' — occupied a 
resolved by adhering to the laws of the sovereign in a way that is both faithful and rational. In this respect, the education system established to ensure that all people become citizens with common values will eliminate threats to the worldly power associated with the church and resulting from the understanding of conscience is alleged to be directly linked to the truth. ${ }^{23}$ For this reason, Hobbes says the professors of the church-centered universities should be retrained. ${ }^{24}$ For Hobbes, the aim of education is to ensure that people rationally obey the law without being influenced by religious and political incitements. ${ }^{25}$

John Locke, who takes a more liberal approach than that of Hobbes, maintains the distinction between synderesis as a natural background and conscientia and defends the preservation of synderesis as the ultimate goal of human life. The production of the conscientia, which is the moral insight that human beings must have in order to conform to the moral life of the society in which they live, depends on the fact that society is not separated from the main orientation associated with synderesis. The function of conscience is related to judgments and convictions about the moral rightness or wrongness of our actions. ${ }^{26}$ Conscience serves as a judicial function based on the laws of nature which vary according to different political situations and environments, but does not guide. Because it does not have the knowledge of the good and the bad, it is variable and personal. ${ }^{27}$ At the same time, according to Locke, just as in any other field, we do not have innate knowledge of conscience either. ${ }^{28}$ The different types of knowledge that we have are shaped by the influences of our experiences and culture after birth. ${ }^{29}$ However, conscience occurs in every person as a sort of 'competence'. ${ }^{30}$ This competence or ability is related to the judgement of the moral actions of the person in itself. ${ }^{31}$ Similar to the ability of language, these criteria do not come from birth and are shaped by education and the experiences acquired from the society we live in. ${ }^{32}$ Locke is concerned with both the recognition of the laws of nature and the assessment of the moral laws of society by the mind. Conscience is not in a managerial position, but in a position of a 'mind-of-the-court'. ${ }^{33}$ Therefore, common moral decisions do not take place spontaneously and compulsorily. This gap can be closed by training and education. Recognizing the fallibility

prominent role in medieval and early modern treatises on conscience." Mark Hanin, pp. 60-61. And also see, Thomas Hobbes, The Elements of Law Natural and Politic, p. 154-155.

23 Thomas Hobbes, The Elements of Law Natural and Politic, p. 183.

24 Thomas Hobbes's Leviathan, p. 264-265.

25 Teresa M. Bejan, Teaching the Leviathan: Thomas Hobbes on Education, Oxford Review of Education, Vol. 36, No 5, October 2010, pp, 607-626, p. 611.

26 John Locke, An Essay Concerning Human Understanding, Dover Publications, INC. New York, 1959, vol. 1., p. 71.

27 Ibid., p. 71

28 Richard Sorabji, Moral Conscience through the Ages: Fifth Century BCE to the Present, The Universty of Chicago Press, Chicago, 2014, p. 152.

29 John Locke, Some Thougts Concerning Education, London, 1779. p. 160-161.

30 John Locke, Assays on The Law of Nature, Edit. By, W. Von Leyden, Oxford at The Clarendon Press, 1954, p. 117.

31 Ibid., p. 117.

32 Mihai Androne, Notes on John Locke’s views on education, Procedia - Social and Behavioral Sciences 137 (2014) $74-79$, p. 75

33 John Locke, An Essay Concerning Human Understanding, p. 343-344. 
of conscience, ${ }^{34}$ Locke attaches importance to education in terms of gaining common values as a precondition for the community to live together. In these educational practices, instead of punishment, coercion and formality, it is important to make sure that rewards, voluntariness and habits are infixed as established character attributes. ${ }^{35}$

Adam Smith considers conscience as an analysis for the comprehension of moral thinking and decision-making processes. What Adam Smith wants to understand is the process of the formation of human moral decision-making and how this cognitive process works. According to him, there is no stage in which moral maturation ends for man. ${ }^{36}$ But the concepts of 'Sympathy' and the 'neutral spectator' as well as their relationships with each other are important for us such that one can come to understand what the sources, human conscience, and how they are formed. The only motivation for living in society is the fact that it is not possible to survive alone. ${ }^{37}$ People seek to be approved by other people in a relationship. ${ }^{38}$ Therefore, they review their moral actions by looking at themselves through the eyes of the others. The 'neutral spectator', on the other hand, is the internalization and embodiment of empathy. ${ }^{39}$ As it is understood from Smith's assessments, the 'neutral spectator' is not 'ideal' because it is created by the self, based on the effects reflected upon it. ${ }^{40}$ In addition, the person knows that, through empathy, he may as well react in a similar way in the situation experienced by the other party. The other party can be approved and rejected. Smith calls this process 'sympathy'. ${ }^{41}$ At the same time, self-evaluation is also possible. Here there occurs a split. The two are completely different self-actors engaged as actors and evaluators. ${ }^{42}$ It is the laws of nature that are effective in this process. Ultimately, the motivation related to the individual's efforts for being worthy of praise is the main motive. ${ }^{43}$ For Smith, education (corporate and informal) means that people living in the same society feel at least the otherness towards each other and eliminating the incompatibility by creating common values. ${ }^{44}$

Immanuel Kant's understanding of conscience is closely related to the idea of enlightenment. Just as he defended the independence of mind, Kant defends the independence of conscience as well. ${ }^{45}$ For Kant conscience is an ability that must be independently empowered by one's

34 Richard Sorabji, p. 152.

35 John Locke, Some Thougts Concerning Education, p. 47-48

36 Jery Evensky, Adam Smith's Moral Philosophy: A Historical And Contemporary Perspective On Markets, Law, Ethics, And Culture. Camridge: Cambridge University Press, 2005. p. 47

37 James R. Otteson, Adam Smith's Marketplace Of Life, Cambridge: Cambridge University Press, 2002, p. 91

38 Adam Smith, The Theory Of Moral Sentiments, Indianapolis: Liberty Fund, 1984. p. 117.

39 Ibid., p. 116.

40 James R. Otteson, p. 70.

41 Jack Russell Weinstein, Adam Smith's Pluralism: Rationality, Education, and the Moral Sentiments, Yale University Press, 1972, p. 73.

42 Adam Smith, The Theory Of Moral Sentiments, p. 113.

43 Ibid., p. 114.

44 Jack Russell Weinstein, p. 68.

45 Immanuel Kant, An Answer to the Question: What is Enlightenment? (1784), In, Immanuel Kant, Practical Philosophy, Translated And Edited By Mary J. Gregor, General Introduction By Allen Wood, Cambridge Universty Press, 1999, s. 17-18. 
own autonomy. ${ }^{46}$ In spite of the convenience of the decision-making afforded to the external authorities, he considers the responsibility to be personal. ${ }^{47}$ Even though the motivation behind one's adjudication of one's own is conscience, the one that makes judgments is not the conscience, but the mind. ${ }^{48}$ Conscience only calls. ${ }^{49}$ At the end of the call, one may experience satisfaction or discontent. In case of discontent, the person inevitably acts in accordance with the decision of conscience. Conscience is about a reflection of self-judgment, and is derived from the duty to know oneself. Consciousness is self-awareness. ${ }^{50}$ In this case, conscience is the "consciousness which is a duty on its own". ${ }^{51}$ In addition, for Kant, the only creature that needs education is the human being. Because it needs to undergo a long care and moral education..$^{52}$ Bringing up as from childhood is a major factor in joining the basic dynamics of morality. Education aiming to cultivate an independent individual is about one's ability to act according to one's own conscience and mind. ${ }^{53}$ In this respect, future goals should be taken into: consideration in education. Kant gives precedence to the discipline and obedience in education and opposes bringing forth punishment system. ${ }^{54}$ In moral education, on the other hand, the aim is personality formation in which maxims are born in mind. ${ }^{55}$

One of the greatest influences on the works in the field of philosophy of ethics in today's Western European world is the Second World War. The results of Stanly Milgram's and Theodor Adorno's works discussing the psychological aspects of the obedience to understand the Nazi world of the time have had dramatic impacts. These influences have also been inevitably visible in the field of morality. In addition to the systematic review of the elements of authority and obedience, which are among the fundamental dynamics of each society, the reliability and responsibility of conscience have begun to be discussed effectively. While Conservatives put responsibility for the results of the order upon the authority, the humanists defend the supremacy of conscience, defending the responsibility of the subject who fulfilled the order. ${ }^{56}$ The shaping of the tension between the conscience and the actions of the subjects with the influence of authority is noteworthy. At the same time, Hannah Arendt's expressions in the Eichmann case raised the question of the extent to which similar behaviors of the individuals who were considered to be

46 Immanuel Kant, The Lectures On Ethics, Translated by Louis Infield, Harper\&Row, Puplishers, New York, 1963, p. 129.

47 Immanuel Kant, An Answer to the Question: What is Enlightenment?, p. 17-18.

48 Immanuel Kant, Religion Within The Boundaries Of Mere Reason, And Other Writings, Translated And Edited By Allen Wood, George Di Giovanni, Cambridge Universty Press, 1998, p. 179.

49 Ibid., p. 178-179. Bunun yanı sıra, insanın ahlak yasası tarafından iyi bir hayat yaşamaya çağrılıyor olması da söz konusudur. Bkz., Ibid., p. 145.

50 Immanuel Kant, Lectures On Ethics, p. 132-133. And, Immanuel Kant, Religion Within The Boundaries Of Mere Reason, And Other Writings, p. 178.

51 Ibid., p. 178.

52 Immanuel Kant, Kant on Education, With an Introduction By C. A. Foley Rhys Davis, M.A., D. C. Health\&Co., Publishers, Boston, 1900, p. 1-2.

53 Ibid., p. 9-11.

54 Ibid., p. 84.

55 Ibid., p. 84.

56 Stanly Milgram, Obedience To Authority: An Experimental View, Tavistock, Harper And Row, Puplishers, 1974, p. 2. 
"abnormal" and those considered to be "healthy" individuals could be distinguished. This suggests the claims that there is a limit to the validity of moral sense, and it is gained by suggestion. ${ }^{57}$ According to Milgram, the moral values of people under obedience have little effect on human beings. ${ }^{58}$ In this case, people can be addressed and discussed in two ways, as in terms of the moral and psychic structures. ${ }^{59}$ The shift in focus and context are also effective elements in the Milgram's experiment. Consequently, although Milgram mentions that the responsibility for behaviors has evaporated, he shows that Hobbes' idea that the moral responsibility rests with the legislator is still widespread and valid. ${ }^{60}$

Similar to Milgram, Erich Fromm, however, goes a step further, arguing that all human history can be read through obedience and disobedience. ${ }^{61}$ Disobedience, which can be seen as an ability?, is the determinative dynamic of human development. ${ }^{62}$ However it does not make sharp and rough distinctions between these two concepts and does not simplify them. Fromm defines two kinds of conscience in relation to this subject: authoritarian conscience and human conscience. While authoritarian conscience is based on fear, human conscience relies on intuitive knowledge found within each person. The authoritarian conscience is the prescriptive, exploitative, close to questioning and it observes its own interests. However, human conscience is also an autonomous conscience. ${ }^{63}$ This criticism is the capitalist critique of the contemporary world. Behaviors of the people whose consumer tendencies have been shaped and who view themselves as individuals in a position to make decisions independent of the authorities can be foreseen by the system. He argues that the solution to the problem that the enlightenment mind has made man dependent on the success and his own productions and its creation of a contemporary crisis lie, again, in the humanistic moral sense. ${ }^{64}$ Humanist morality works together with the concept of "human nature". The human nature described by Fromm is that man is innately productive and good. At the same time, the humanist conception of conscience maintains the ground of socialization. However it is also important that the network of relations is organized in such a way as to enable the realization of conscience. ${ }^{65}$

Theodor W. Adorno cannot go beyond the tradition of enlightenment and tries to maintain traditional bourgeois thought, as if he wants to exempt the relationship among the state, human reason and goodness from criticism. One of the important concepts for Adorno is stereotype (cliché). ${ }^{66}$ While clichés can provide 'ease' of views and a rapid attitude development, they cannot

57 Ibid., p. 5.

58 Ibid., p. 1.

59 Ibid., p.7.

60 Ibid., p. 11.

61 Erich Fromm On Disobedience: Why Freedom Means Saying "No" To Power, Perennial Modern Thought Edition Puplished, 2010, p. 3-5.

62 Ibid., pp. 3-4.

63 Ibid., p. 6.

64 Erich Fromm, Erich, Man for Himself: An Inquiry Into the Psychology of Ethics, Routledge, 2002, p. 6.

65 Ibid., p. 6-7.

66 Franco Ferarotti, International Journal of Politics, Culture, and Society, Vol. 8, No. 1 (Autumn, 1994), pp. (105127), p. 105. 
be corrected by experiences in real situations as they can develop as an unconscious beliefs. ${ }^{67}$ They can be explicitly or implicitly adopted by people as prejudices. Although Adorno, as for the enlightenment tradition, accept and adopt the idea that the human being is a good entity in its essence, he states that human beings can do evil with their innate inclinations and the clichés acquired through tendencies in language and culture. ${ }^{68}$ According to Adorno, the solution to this lies in the preparation of education and the appropriate environment. It is not a matter of educating people in a closed environment but an educational system that can develop their own authenticity and autonomy, as well as the preparation of a living environment based on egalitarian social life and where social experiences can be realized freely. ${ }^{69}$

Zygmunt Bauman argues that the source of the tragedies of the Second World War are sociocultural orientations and supports encouraging and propping up the innate personality traits. ${ }^{70}$ Bauman also attaches importance to behavioral conditioning. The act of evil can arise through encouragement by society of ordinary people to do evil. In this respect, it is not the individual who should be judged, but the social forms of understanding. ${ }^{71}$ The "myth of the rational order" has also been destroyed, and it cannot ensure the production of moral actions by itself. ${ }^{72}$ In any case, even if they are not defined as crimes in the law, acts that are contrary to the values of humanity cause discomfort in one's conscience. ${ }^{73}$ Unconditional obedience is an obstacle to the activation of the moral stimulus. ${ }^{74}$ In this respect, social relationships should be arranged in such a way that they do not suppress conscientious responsibility in the face of the official duty or bureaucracy. ${ }^{75}$

In Agnes Heller, the concept that stands out is supererogatory. ${ }^{76}$ This concept means that the person has an unquestioned action. This situation involves a dilemma. The person is on the border with the compulsion and necessity to make a choice between the officially promised duty to authority and the moral authority the person feels responsible against. A Superrogatory action is one that the person is willing to be guilty of in order to be "good" at this border? The different moral criteria of different authorities and the heresy of one period is recognized as the pioneers in

67 Max Horkheimer, Studies In Prejudice, Edited By M A X Horkheimer And Samuel H. Flowerman, The Authoritarian Personality, By T. W. Adorno, Else Frenkel-Brunsivik, Daniel J. Levinson And R. Nevitt Sanford, Harper, New York, 1950, p. 617.

68 Ibid., p. 618.

69 Shannon L. Mariotti, Adorno and Democracy, Chapter Title: Democratic Pedagogy: Resistance and an Alternative Model for Civic Education, University Press of Kentucky, 2016, p. 113.

70 Zygmund Bauman, Collateral Damage: Social Inequalities in a Global Age, Polyt Press, 2011, p. 133.

71 Ibid., p. 133.

72 Zygmunt Bauman, Modernity and The Holocaust, Polity Press, 2008, p. 150.

73 Zygmund Bauman, Collateral Damage: Social Inequalities in a Global Age, p. 75.

74 Zygmunt Bauman, Modernity and The Holocaust, p 23.

75 Ibid., p. 150.

76 Agnes Heller, General Ethics, Basic Blackwell, Massachusestts, 1990, p. 67. The thinker who puts this concept on the agenda of moral philosophy is J. Urmson. According to Urmson, superrogatory action is a neglect of traditional moral theories. The feature of this area is to exceed the best treatment area for the person and take risks. See: J. O. Urmson, 'Saints and Heroes', in Essays in Moral Philosophy, A. I. Melden (ed.) University of Washington Press, 1958. But this situation raises a debate about the moral position of the saints or sages. This is because this behavior, which is admired and approved, should be a general and common form of behavior. For discussion, see: Elizabeth M. Pybus, Saints and Heroes, Philosophy, Vol. 57, No. 220 (Apr., 1982), pp. (193-199), p. 193-195. 
other periods. In this respect, Heller calls the responsibility of the leaders in superrogatory action, using the chance they have caught, as the enormous responsibility. ${ }^{77}$ Because this action is against the general moral conceptions. In the other case, it is clear how normative expectations will be fulfilled. In this boundary environment phronesis is also activated. Phronesis and superrogatory action are in contradiction. ${ }^{78}$ For phronesis, which expresses the knowledge of practical action, according to Aristotle, there is a need for experience and practice, and it is a virtue associated with the supposition. ${ }^{79}$ Furthermore, a certain value and human understanding is decisive for phorenesis. However, the knowledge of whether an action is superrrogatory action can be understood after the action. Further two important concepts emerge here: the 'contingency of the individual' and 'his jump to the emptiness in the moral actions of the individual'. ${ }^{80}$ The modern human being with no innate purpose and literally thrown into the world is contingent. Modern people choose their own purposes, but the source of these elections is also contingent. The action of such an understanding is expressed by the metaphor of 'jumping into space'. ${ }^{81}$

Although contingency is not a new concept, it has gained current popularity with Richard M. Rorty. ${ }^{82}$ Contingency is a form of grasping, and what is meant by the one that is contingent is that it does not necessarily exist the way it is, it can exist otherwise. At the same time, the contingency of language has led human beings to the awareness that this diversifies them and their perception of the universe. ${ }^{83}$ The real problem is how people will keep living on earth in a world with no truths. The problem raised by Rorty is whether there will be a possibility of a moral life in such a world.$^{84}$ Rorty proposes a historicist perspective with respect to any attempt to define conscience, in case the exit from the cultural context is questionable and the conscience is reproduced; he argues that the perspective towards comprehending the current situations within their historicity will be more successful. Those who argue that human beings have an essence and that there is no background other than their historicity constitute two main lines of views about human nature. According to this second group of people, including Rorty, the realities of human beings are the culture and civilization formed by sociality and life experiences.

A historicist perspective and the awareness that human beings are a measure and hope to reduce moral evil in the world. In the end, it is aimed to establish and sustain moral solidarity among people without relying on an essential background. In this understanding, language is not seen as a mere tool. Changing language means changing all forms of comprehension. This discovery has been taken into account when developing the basic methods used in the field

77 Agnes Heller, General Ethics, p. 78.

78 Ibid., p. 101.

79 Aristotle, Nicomachean Ethics, Translated an Edited By Roger Crisp, Cambridege, Cambridge University Ptess, 2000, 1142a and 1140 b 25 .

80 John Grumley, The Ethical Imperative, Agnes Heller: A Moralist in the Vortex of History, Pluto Press, 2005 , p. 198.

81 Agnes Heller, A Philosophy of Morals, Basic Blackwell, Massachusetts, 1990, p. 5.

82 Relativism: Interpretation and Confrontation, Michael Krausz(ED.) Notre Dame: University of Notre Dane Press, 1989) Richard Rorty, Solidarity or Objectivity?, p. 170.

83 Richard Rorty, Contingency, Irony, and Solidarity, Cambridge University Press, 1999, p. xiii.

84 Wehan Murray Coombs, Contingency, Irony and Morality: A Critical Review of Rorty's Notion of the Liberal Utopia, Humanities 2013, 2, (313-327), p. 317. 
of education. More importantly, the universal and objective rationality which is constructed from an 'enlightened' perspective also takes its share of the destructive criticism of contingency. However, this does not mean that universal values do not exist or cannot be advocated, but it is only about the redundancy of unshakable and implicit truth assumptions. Instead of absolute understandings, "honestly" defended values will only be accepted as "proposals" just like the others. In human education, in a similar way, the aim should be to create a human 'mass' that supports neither the necessity of an understanding of truthfulness provided in return for enabling of sociality nor a form of individualism that is completely driven away from collectivism. On the contrary, it is about creation and maintenance of a common living environment by transferring values from a perspective of the past and the future, and supporting the critical thinking and establishment of an open relationship.

Grant Support: This study was prepared between September 2018 and February 2019 within the scope of the research project titled Conscience and Values Education conducted in the Department of Philosophy at the University of Duquesne, Pittsburgh, USA, with a Postdoctoral Fellowship in Tübitak (The Scientific and Technological Reserch Concil of Turkey).

\section{References}

Adam Smith, The Theory Of Moral Sentiments, Liberty Fund, Indianapolis, 1984.

Agnes Heller, A Philosophy of Morals, Basic Blackwell, Massachusetts, 1990.

Agnes Heller, General Ethics, Basic Blackwell, Massachusestts, 1990.

Aristotle, Nicomachean Ethics, Translated an Edited By Roger Crisp, Cambridege, Cambridge University Ptess, 2000.

Douglas Langston, The Spark of Conscience: Bonaventure's View of Conscience and Synderesis, Franciscan Studies, Volume 53, 1993, pp. 79-95.

Elizabeth M. Pybus, Saints and Heroes, Philosophy, Vol. 57, No. 220 (Apr., 1982), pp. (193-199)

Erich Fromm On Disobedience: Why Freedom Means Saying "No" To Power, Perennial Modern Thought Edition Puplished, 2010.

Erich Fromm, Erich, Man for Himself: An Inquiry Into the Psychology of Ethics, Routledge, 2002.

Franco Ferarotti, International Journal of Politics, Culture, and Society, Vol. 8, No. 1 (Autumn, 1994), pp. $(105-127)$

Hobbes's Leviathan, Reprinted From The Edition Of 1651 With An Essay By The Late W. G. Pogson Smith, Oxford At The Clerandon Press, London, 1965.

Immanuel Kant, An Answer to the Question: What is Enlightenment? (1784), In, Immanuel Kant, Practical Philosophy, Translated And Edited By Mary J. Gregor, General Introduction By Allen Wood, Cambridge Universty Press, 1999.

Immanuel Kant, Kant on Education, With an Introduction By C. A. Foley Rhys Davis, M.A., D. C. Health\&Co., Publishers, Boston, 1900.,

Immanuel Kant, Religion Within The Boundaries Of Mere Reason, And Other Writings, Translated And Edited By Allen Wood, George Di Giovanni, Cambridge Universty Press, 1998.

Immanuel Kant, The Lectures On Ethics, Translated by Louis Infield, Harper\&Row, Puplishers, New York, 1963.

J. O. Urmson, 'Saints and Heroes', in Essays in Moral Philosophy, A. I. Melden (ed.) University of Washington Press, 1958. 
Jack Russell Weinstein, Adam Smith's Pluralism: Rationality, Education, and the Moral Sentiments, Yale University Press, 1972.

James R. Otteson, Adam Smith’s Marketplace Of Life, Cambridge: Cambridge University Press, 2002.

Jery Evensky, Adam Smith's Moral Philosophy: A Historical And Contemporary Perspective On Markets, Law, Ethics, And Culture. Camridge: Cambridge University Press, 2005.

John Grumley, The Ethical Imperative, Agnes Heller: A Moralist in the Vortex of History, Pluto Press, 2005. John Locke, An Essay Concerning Human Understanding, Dover Publications, INC. New York, 1959.

John Locke, Assays on The Law of Nature, Edit. By, W. Von Leyden, Oxford at The Clarendon Press, 1954. John Locke, Some Thougts Concerning Education, London, 1779.

Mark Hanin, Thomas Hobbes's Theory Of Conscience History Of Political Thought. Vol. Xxxiii. No. 1. Spring 2012.

Max Horkheimer, Studies In Prejudice, Edited By Max Horkheimer And Samuel H. Flowerman, The Authoritarian Personality, By T. W. Adorno, Else Frenkel-Brunsivik, Daniel J. Levinson And R. Nevitt Sanford, Harper, New York, 1950.

Mihai Androne, Notes on John Locke's views on education, Procedia - Social and Behavioral Sciences 137 (2014) pp. $(74-79)$

Paul Strohm, Conscience, A Very Short Introduction, Oxford University Press, New York, 2011.

Relativism: Interpretation and Confrontation, Michael Krausz(ED.) Notre Dame: University of Notre Dane Press, 1989) Richard Rorty, Solidarity or Objectivity?

Richard Rorty, Contingency, Irony, and Solidarity, Cambridge University Press, 1999.

Richard Sorabji, Moral Conscience through the Ages: Fifth Century BCE to the Present, The Universty of Chicago Press, Chicago, 2014.

Shannon L. Mariotti, Adorno and Democracy, Chapter Title: Democratic Pedagogy: Resistance and an Alternative Model for Civic Education, University Press of Kentucky, 2016.

Stanly Milgram, Obedience To Authority: An Experimental View, Tavistock, Harper And Row, Puplishers, 1974.

Teresa M. Bejan, Teaching the Leviathan: Thomas Hobbes on Education, Oxford Review of Education, Vol. 36, No 5, October 2010, pp. (607-626)

Thomas Hobbes, De Cive, Edited by Howard Warrender, Oxford At The Clerendon Press, 1987.

Thomas Hobbes, The Elements of Law Natural and Politic. Edited With A Preface And Critical Notes By Ferdinand Tönnies, Simpkin, Marhall, and Co., London, 1889.

Timothy C. Potts, Conscientia in Medival Philosophy, Cambridge University Press, 1980.

Wehan Murray Coombs, Contingency, Irony and Morality: A Critical Review of Rorty's Notion of the Liberal Utopia, Humanities 2013, 2, pp. (313-327).

Zygmund Bauman, Collateral Damage: Social Inequalities in a Global Age, Polyt Press, 2011.

Zygmunt Bauman, Modernity and The Holocaust, Polity Press, 2008. 